\title{
Barriers to the Adoption of BOT Contracts System for Infrastructural Development of Technical Universities in Ghana
}

\author{
Harold Adjarko, Hiob Ayerakwah, John Fynn \\ Building Technology, Faculty of Built and Natural Environment, Takoradi Technical University, Takoradi, Ghana \\ Email: haroldadjarko@gmail.com
}

How to cite this paper: Adjarko, H., Ayerakwah, H. and Fynn, J. (2018) Barriers to the Adoption of BOT Contracts System for Infrastructural Development of Technical Universities in Ghana. Journal of Building Construction and Planning Research, 6, 103-111.

https://doi.org/10.4236/jbcpr.2018.63007

Received: May 31, 2018

Accepted: July 20, 2018

Published: July 23, 2018

Copyright $\odot 2018$ by authors and Scientific Research Publishing Inc. This work is licensed under the Creative Commons Attribution-NonCommercial International License (CC BY-NC 4.0).

http://creativecommons.org/licenses/by-nc/4.0/

\begin{abstract}
The study was conducted with the aim of exploring the barriers to the adoption of BOT contract systems for infrastructural development of technical universities in Ghana. In an empirical questionnaire survey with professionals and experts in the construction and education sector, the respondents were invited to rate their perception on the barriers to the adoption of the BOT contracts systems. An interview session to satisfy ways of adopting the BOT contracts for infrastructural development in technical universities was conducted with selected professionals. The study revealed that the major barriers to the adoption of the BOT contract system are: delays in approval, corruption, reliability and credit worthiness of entities and expropriation. The study suggested that detailed policy or framework for implementing BOT contracts; proper planning by technical universities; and adequate protection for lenders is required for successful BOT implementation. Therefore there is a need to explore this concept, using adequate policy initiatives, proper measures and support from government to improve on the proper implementation of the BOT contracts in Technical Universities in Ghana.
\end{abstract}

\section{Keywords}

Ghana, Build Operate Transfer (BOT) Contracts, Technical Universities in Ghana

\section{Introduction}

The BOT contracts system which is a Public Private Partnerships (PPP) approach is growing and evolving globally, as more countries move from state-owned and operated services to the private provision of infrastructure. Since the 1990s, there has been a rapid rise of Public Private Partnerships (PPPs) 
arrangements across the world. Governments in developing nations are taking advantage and using PPP arrangements to improve delivery of public infrastructure. For example, the private sector is estimated to have invested $\$ 750$ billion in infrastructure in developing countries between 1990 and 2001 [1]. In the year 2015, the government of Ghana hastened the process of transforming the country's polytechnics into technical universities and with improved methods of studies in these institutions. It has said that this would ensure skills training at the polytechnics, which was the surest way of curbing youth unemployment in the country [2]. Facilities in these institutions require improvement as quickly as possible. The BOT method of contracting which is a PPP arrangement has been identified by many researchers as one way to accelerate infrastructural development in the public sector. In the PPP definition in the Ghanaian context, three clear features are articulated. Firstly, it must be a partnership and a contractual arrangement between two parties where one party is a Public Entity. Most often, the public entity is referred to as a Contracting Authority. The Contracting Authorities include; Metropolitan, Municipal and District Assemblies, Ministries, Public Agencies and Departments. The Ministry of Finance and Economic Planning (MOFEP) through its Public Investment Division (PID) offers assistance to the Contracting Authorities throughout the PPP process. Secondly, PPP is the sharing of responsibilities and risk. In fact the Government of Ghana has indicated that any transaction or partnership without a shared risk over a period of time cannot be considered as PPP [3]. Finally, a transaction can be considered to be PPP only if the private partner executes a public infrastructure project whose provision is traditionally deemed to be done by the public sector. Thus, public infrastructure projects are considered as PPP only when they are financed and executed by the private sector. There is unarguably inadequate infrastructure in the polytechnics in Ghana, and also with the suspension of many ongoing projects due to lack of funds, there is a serious need to innovative ways to deal with the infrastructural deficit. These institutions keep on appealing to the government for quick and timely release of funds to complete the infrastructural deficit. It is evident in Ghana that, in spite of the recent upsurge in construction activities such as road construction, building construction, construction of bridges and others, the focus has not been directed to infrastructural improvement in the Technical Universities. It is obvious that the pressure on government is enormous. Most public institutions do not consider BOT contract principles in their construction procurement decisions resulting in a general low patronage of these PPP principles among the public sector. This study identified various barriers to the use of the BOT contract principles for infrastructural development of technical universities.

\section{Previous Research}

\subsection{Overview of the Build Operate Transfer (BOT) Contracts}

Augenblick and Custor [4] states that, in a typical BOT infrastructure project, a private sector project company builds a project, operates it long enough to pay- 
back project debt and equity investment, than transfer it to the host government. But if the same BOT project can be implemented as a turnkey construction contract financed by sovereign borrowing, the time saved and the great certainty of the project going forward may warrant the more traditional approach. Build-Operate-Transfer (BOT) simply describes a model or structure that uses private investment to undertake what has historically been public sector infrastructure development. UNIDO BOT Guidelines [5], states that in a BOT project a private company is given a concession to build and operate a facility that would normally be undertaken by the government. It might be a power plant, airport, toll road, and tunnel or water treatment facility. The private company is also responsible for financing and designing the project. At the end of the concession period the private company returns ownership of the project to the government. The concession period is determined primarily by length of time needed for the facility's revenue stream to pay off the sponsor's debt and provide a reasonable rate of return for their effort and risk.

\subsection{The Structure of BOT Contract}

Mubin and Ghaffar [6] explains that in BOT projects, private sector bear the cost of project first, and then owns it for certain period before handing it over to the government at no cost. Mubin and Ghaffar [6], further explains that BOT projects are usually, but not necessarily, public infrastructure projects which employ a particular form of structured financing. As these projects are generally long live projects, therefore it is also demanded that the political and government system must be stable enough to ensure the return/pay back of the investors to minimize their financial risks. As the productive life of a project varies depending upon the type of project and structure therefore sometimes it makes complication in formulation of policies and regulations of BOT so that all the parties remain in benefit. Since BOT projects are ultimately transferred to the government after the payback period, hence the public of the country is actually the beneficiaries or the end user of these projects.

\subsection{The Effective Implementation of BOT}

According to Adeagbo and Kolawole [7], information on the implementation of BOT contractual arrangement can only be obtained from construction firms, financial institutions, legal practitioners, architects, quantity surveyors arid building developers. In fact information on the implementation of BOT will not be sufficient without seeking information from investors who are the main sponsors. Legal and financial problems were the main implications of BOT contract implementation from their study. Correlation test between legal and financial problems in BOT implementation showed a negative relationship. The inference then is that legal problem is distinct from financial problem.

\subsection{Sources of Finance}

As stated by Ahmed et al. [8], companies can raise equity finance from institu- 
tions and private investors through either public or private sources. Public sources include a full stock exchange listing, where the company is required to have an established trading record with a minimum of five unqualified accounts. Private sources of equity finance include institutions that provide venture or development capital as enumerated above. A further source of finance is through a private placing whereby shares are brought by an institution through an arrangement which is normally negotiated through an intermediary such as a merchant bank.

\subsection{Barriers to the Adoption of BOT Contracts System}

The key to a successful implementation of a BOT infrastructure project is an in-depth analysis of all aspects related to economic, environmental, social, political, legal, and financial feasibility of the project. For these reasons, the analysis of project feasibility decision needs a technique to include the qualitative decision, factors that have the strong impact on the project [8]. Some challenges for the government have been identified as: different typologies of partnership requiring different kind of regulation and control; broad supervision, but close tracking of market feed back; resistance from within the organization; political benefit-cost is strong to enter partnership but at operation points resistance emerges; strong legal provisions of agreement and counterpart obligations for transparency and customer friendliness; equality and fairness is the name of the game [1].

Some other key barriers include:

\section{1) Change In Law}

According to Wang [9], change in law risk includes changes in government policies with respect to laws and regulations, methods to address inflation, currency conversion, rates and methods of taxation, and the method by which electricity tariffs are set and approved. This obviously adversely affects investors' decision to engage in partnership deals with certain countries.

\section{2) Corruption}

Corruption is regarded by many companies as an unavoidable fact of life on projects in developing countries. Corruption risk is based on using political, legal, or regulatory leverage to extract additional costs for which no one will ever admit and the project developer can never recoup. It occurs when the government's officials and representatives solicit or receive an unlawful consideration or commission or exert or utilize any unlawful influence in connection with awarding and agreement to the project developer. This presents the risk of either spending too much money on corrupt officials or spending money in the wrong places or at the wrong times all at the risk of having a government agency turn against the project developer and the project [10].

\section{3) Delay in Approval}

Delay in approval risk means that the central or local government authority does not approve the project-related issues in time or even cancels the already 
approved ones. Obtaining approvals for a project from a complex web of government agencies and departments, from municipal to central government levels, can be an extremely time-consuming process, delaying entire projects and hurting their financial viability [9]. In Ghana, the public procurement authority, which must approve any public infrastructure, is generally regarded as being slow in its review processes.

\section{4) Expropriation}

Expropriation risk occurs when the government expropriates the project without giving reasonable compensation to the project developer and investor, etc. The expropriation can take the form of nationalization of a facility wholesale (rare) or "creeping" expropriation whereby the government changes regulations, taxes, or tariffs after a project is complete to gradually take over the facility and its operating profits (common) [9].

\section{5) Entities' Reliability and Credibility}

For a BOT project, many entities such as partners, contractors, customers, suppliers, operators, guarantors, lenders, and others, who are parties to agreements with foreign parties, will be involved. The success of a project will hence rely on the reliability and creditworthiness of these entities [9]. Although it is said that these stakeholders have the ability and willingness to perform their obligations, the reliability and creditworthiness of such stakeholders are difficult to ascertain.

\section{6) Force Majeure}

According to public procurement Act, Act 663 [11], force majeure refers to circumstances such as natural disasters or accidents beyond the control government. Examples are fires, floods, storms, and earthquakes, wars, hostilities, embargoes, and import and export restrictions.

\subsection{Ways to Promote Effective BOT Contracts System}

According to the Asian Development Bank [1] of the Department of Economic Affairs (DEA) Ministry of Finance, Government of India, the following are some Key lessons from global experience with PPP on ways to promote effective BOT contracts management: detailed policy for implementing PPP; proper planning by government institution; project development by government; full support by government; proactive public communication; transparent bidding process; clear policy on unsolicited proposals; defined sources of revenue; proper allocation of risk; and adequate protection for lenders.

\section{Research Method}

The study adopts the survey research design. Purposive sampling was used to solicit information from professionals selected from five Polytechnics that have been transitioned into technical universities in Ghana. The institutions included Takoradi Technical University, Accra Technical University, Kumasi Technical University Koforidua Technical University and Ho Technical University. The 
study made use of questionnaire which constituted the major tool of the research and an interview session for selected respondents with experience on subject matter. One set of questionnaire was issued out. The questionnaire was issued out to engineers, architects, quantity surveyors and selected professionals in the development offices of the selected Technical University with respect to the objectives of the study. The inclusion of these knowledgeable officers helped the researchers to know the relevant BOT principles that could be applied in the sector. The questions covered barriers to the adoption of BOT contracts for the accelerated infrastructural development in technical universities. Data obtained from the survey was analyzed by Mean Score (MS) rankings. The interview session followed the questionnaire to satisfy the third objective a propos identifying ways of incorporating the BOT contract into the construction procurement system of technical universities in Ghana.

\section{Results and Discussion}

\subsection{Years of Experience in the Construction Sector}

Based on their number of years of experience, it shows that out of (20) respondents representing (100\%), the majority of the respondents (6) representing professionals with working experience of both $6-10$ years and $11-15$ years making (12) respondents representing $60 \%$ as the highest percentage, (5) respondents representing professionals with working experience of 20 years and above as the remaining (3) respondents are professionals with working experience below 5 years. The analysis for Figure 1 indicates that majority of the respondents had working experience over 6 years with just a few below 5 years. This also credits data collected since most of the respondents had many years of experience and knowledge of the Ghanaian construction industry. However the low patronage of BOT principles in the sector is explained by the fact that most of these principles are new to them and that they are more familiar with the traditional procurement methods. This problem could be addressed through workshops on PPP principles and applicability.

\subsection{Barriers to the Adoption of BOT Contracts for the Infrastructural Development of Technical Universities in Ghana}

The Table 1 shows the Barriers adoption of BOT Contracts for the Infrastructural Development of Technical Universities in Ghana:

From the Table 1, the mean of 4.85 which is the highest of the (20) respondents representing delay in approval of government projects. Also, the second highest of the mean was 4.80 which represents the corruption among the project participants. The next highest was 4.75 , representing the reliability and credit worthiness of entities. Again the next was 4.70 of the respondents representing expropriation. Furthermore, 4.45 represent change in law of state. Also the next was 4.35 representing force majeure in that order respectively. The highest of the 


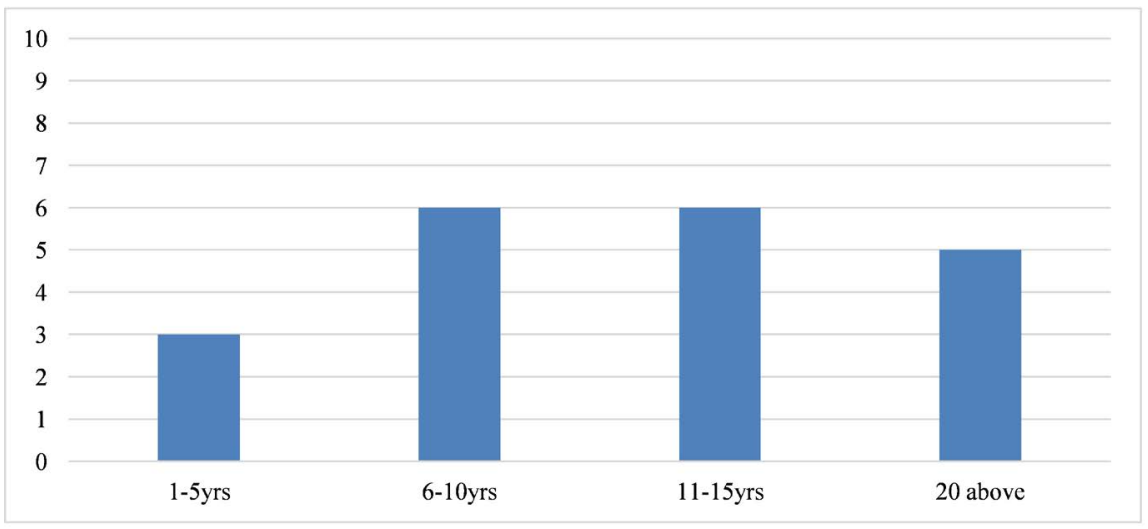

Figure 1. Years of experience in the construction sector (Source: Field Survey, 2016).

Table 1. Statistical table representing the barriers to the adoption of BOT contracts for the infrastructural development of polytechnics in ghana.

\begin{tabular}{lccc}
\hline BARRIERS TO CLIENT (GOVERNMENT AGENCY) & N & Mean & Ranking \\
\hline 1) Delays in approval & 20 & 4.85 & $1^{\text {st }}$ \\
2) Corruption & 20 & 4.80 & $2^{\text {nd }}$ \\
3) Reliability and credit worthiness of entities & 20 & 4.75 & $3^{\text {rd }}$ \\
4) Expropriation & 20 & 4.70 & $4^{\text {th }}$ \\
5) Change in law & 20 & 4.45 & $5^{\text {th }}$ \\
6) Force Majeure & 20 & 4.35 & $6^{\text {th }}$ \\
\hline
\end{tabular}

(20) respondents representing delay in approval of government projects agrees with what was found by Wang [9]. Respondents explained that the real challenge with delay has been in assessing projects that are well defined, credibly structured, rigorously appraised, and financially viable. Also, the second highest represents the corruption among the project participants as reviewed by Wang [9]. According to Macdonald [10] the risk of either spending too much money on corrupt officials or spending money in the wrong places or at the wrong times is a major barrier to the adoption of BOT contract system. Many government projects have suffered from time and cost overruns, quality issues, noneconomic allocation criteria, irregular cash flows from budgets, and shortage of competent people. The underlying issue is often corruption. PPPs involve large-scale investments, and the costs of non-completion/unsuccessful operations due to delays and corruption would affect many, also risking the success of future BOT development in the country. The study revealed that though the private sector has welcomed moves to invest in BOT contracts the fear is that these positive steps run the risk of getting undermined by inappropriate and manipulated bidding procedures through corruption. The need for maintaining transparency in the entire BOT project cycle and stakeholder interactions has been highlighted as a key factor in determining the success. Respondents indicated that governments and other public sector project sponsors need to be cau- 
tious about the sole sourcing procurement method, which cannot be equated to transparency.The third highest challenge is reliability and credit worthiness of entities, because it is often difficult to ascertain such values. Although it is said that these stakeholders have the ability and willingness to perform their obligations, the reliability and creditworthiness of such stakeholders are difficult to establish. Many experts attribute the failure of some of BOT projects to faulty, rushed, noncompetitive, and nontransparent application of the BOT principles [12]. Expropriation risk was identified as the fourth highest challenge in the adoption of BOT contract principles. This occurs when the government expropriates the project without giving reasonable compensation to the project developers and investors, etc. Infrastructure projects have a long gestation and often long-term debt funds, respondents explained that investors fear that changes in government priorities may lead to expropriation. Given the large resource requirements and the budgetary and borrowing constraints, government should put in measures to assure and encourage private sector investment and participation in all sectors of infrastructure. Respondents recognized that while public investment in infrastructure would continue to increase, private investors need full support ad commitment from government. Through the interviews respondents elaborated on ways to promote the BOT system for contracts. Their suggestions include the following: that the institutions should make the proposal and not the private party, this could be done through the creation of an environment where BOT contracts are seen to be a way of attracting private money into public projects, with mutual benefits [13]. Also it was revealed that the BOT contract condition should ensure that the project is developed, financed, constructed, maintained, and operated for the project term, which is the concession period, by the private sector company. Again, the private sector company is to be selected by government or a tertiary institution through a transparent and competitive bidding process; which means that the project has to be identified by the state as desirable and then bid out, thus reducing unnecessary delays.

\section{Conclusion}

Infrastructure is seen as the necessary condition for growth of technical universities. The paper concludes that the major barriers to the adoption of BOT contracts for infrastructural development of technical universities in Ghana are as follows: delay in approval, corruption, reliability and credit worthiness of entities and expropriation. With the above listed barriers to the adoption of the BOT contracts, governments need to develop the framework for public institutions, particularly technical universities that would contain adequate measures, policies, support and education to reduce delays and corruption and prevent such bad practices that hinders the growth of technical education in Ghana. Technical universities capacity to successfully execute BOT contracts needs to be built up rapidly. The capacity deficit and lack of a framework is seen as the crucial bottleneck for achieving a steady flow of successfully negotiated BOT deals. The fact 
that the BOT approach is a new, complex, and lengthy way of doing business in a multi-stakeholder institutional arrangement requires that measures are put in place to address the barriers identified in this research.

\section{References}

[1] Asian Development Bank (2006) Facilitating Public-Private Partnership for Accelerated Infrastructure Development in India Regional Workshops of Chief Secretaries on Public-Private Partnership. Workshop Report 2016, New Delhi, July, 2006.

[2] Ghana News Agency (2015) http://www.ghananewsagency.org/

[3] Ministry of Finance and Economic Planning (2011) National Policy on Public Private Partnerships. Government of Ghana, Ghana.

[4] Augenblick, M. and Custer, B.S. (1990) The Build Operate and Transfer Approach to Infrastructure Projects in Developing Countries. Policy Research and External Affairs Working Papers, Urban Development Department, The World Bank, Geneva.

[5] UN (1995) UNIDO BOT Guidelines. Geneva.

[6] Mubin, S. and Ghafar, A. (2008) BOT Contracts: Applicability in Pakistan for Infrastructure Development. Pakistan Journal of Engineering and Applied Sciences, 3, 33-36.

[7] Adeagbo and Kolawole (1999) Problems and Prospects of Build-Own-Operate-Transfer Contractual Arrangement in Nigeria. University of Jos, Jos.

[8] Ahmed, F.M.S., Miroslaw, J.S., and Ismail, B. (2007) BOT Viability Models for Large Scale Infrastructure Projects. Journal of Construction Engineering and Management, 133, 50-63. https://doi.org/10.1061/(ASCE)0733-9364(2007)133:1(50)

[9] Wang, S.Q., et al. (2000) Evaluation and Management of Political Risks in China's BOT Projects. Journal of Construction Engineering and Management, 126, 242-250.

[10] Macdonald, R. (1997) Chinese BOT Risks. Research and Reports, Tokyo University, Tokyo.

[11] Public Procurement Authority (2003) Public Procurement Act, 2003 (Act 663). Accra, Ghana.

[12] Chan D.W.M., Chan A.P.C. and Lam P.T.I. (2006) A Feasibility Study of the Implementation of Public Private Partnership (PPP) in Hong Kong. Proceedings of the CIB W89 International Conference on Building Education and Research, Hong Kong, 10-13 April 2006.

[13] Cheung, E., Chan, A.P.C. and Kajewski, S. (2009). Reasons for Implementing Public Private Partnership Projects: Perspectives from Hong Kong, Australian and British Practitioners. Journal of Property Investment \& Finance, 27, 8195. https://doi.org/10.1108/14635780910926685 